\title{
Messages of parents affection for children in the movie bulan terbelah di langit amerika
}

\author{
Muhammad Ikhsan Jati Kusuma a,1,*, \\ a Goverment of Sleman Residence, Jl Parasamya Tirtodado, Sleman 55511, Indonesia \\ ${ }^{1}$ mijk.182@gmail.com \\ * corresponding author
}

ARTICLE INFO

Article history

Received 2019-09-15

Revised 2019-09-18

Accepted 2019-09-19

Keywords

Message

Peace

Movie

Communication

Affection

\section{ABSTRACT}

This study aims to explain how the message of peace and what peace messages are featured in the movie. This type of research is qualitative. Researchers analyze the signs that appear in the drawings and dialogue using semiotic analysis of Charles Sander Pierce model, as well as classify in Pierce type of icons, indexes, and symbols. The result of this research is that to the moviemakers, researchers hope that every production of movies should consider the interests of the wider community, not only about idealism alone should pay attention to the nature of the media itself, namely informative, educative, and also entertaining As modeled after the Bulan terbelah di Langit Amerika.

This is an open access article under the CC-BY-SA license.

\section{Introduction}

The development of moviemaking, is a mixture of various elements, such as ideas, value systems, views on life, beauty, norms, human behavior, and technological sophistication; thus the movie is not value-free, but instead There is a message developed as a collective work [1]. Therefore, the message is essential for the audience, because the movie is not merely a fictional media entertainment, but rather a reflection of the reality in society [2], so that the movie must be Considering the various elements above to fit the message representing the truth of reality, it helps the function of the movie in general, namely as information media, educational media and entertainment media [3]. However, in reality, the abandonment of the above principles is not infrequently ignored by movie art workers, so there is often a misunderstanding about the message that is conveyed and raises new thinking [4].

In one historical twist, the audience was treated to a new image of Muslims, namely that Muslims often engage in acts of terrorism. In this period, Hollywood Cinema attempted to bring out a message that had tendencies to a new term called "Islamic terrorist." [5] Jack Shahin, an Islamic writer who for many years, researched American performance in presenting cliché and inappropriate description of the Islamic world [6]. The movie, a message containing stereotypes or bad imagery of Islam, can be formed in such a way that it looks so real. Jean Baudrillard, a post-structuralism thinker who introduced the concept of simulated worlds [7]. A variety of poorly imagery or beautiful displays can be presented/staged as real but true to engineering. In the world of simulation, apply legal Simulacra, namely "recycling or reproduction of objects and events." The object or event was demonstrated as if it were the same or reflected the original reality, but truly virtual [8].

Sincerely, "It is hard to predict the real things of the things that simulate the real thing." Through the broader functioning of the movie, the western world makes use of it to form the reality of Islam 
as a denomination of hatred and violence. However, in the midst of the flow of movies that carry stereotypical elements of terrorism against Islam, there are also religious-inspired movies that carry a defense mission against Islam that has been labeled as a terrorist religion, including a movie titled The Bulan Terbelah di Langit Amerika is one of the products of Indonesian Muslim syndicate in delivering a message of peace that Islam is not a religion that teaches terror and violence but Islam has the principle and belief that Our fellow human beings should be able to establish peace despite different religions, ethnicity, tribes, languages, and races.

In this movie about a Muslim family who feels injustice from the news of the mass media in America, this happens because her husband is accused of being one of the terrorist actors in the WTC tragedy, Azima gets the treatment Unfair even as to the consequences of enduring the allegations addressed to her husband. While on the other hand there is a Muslim woman who works as a journalist tasked to make news of the WTC tragedy by taking the source of two perspectives, one of which is the unexpected wife of the WTC bombing. Hanum, as a journalist attempted to help the small family to defend the allegations through the article, he was doing. In principle, Hanum wanted to explain through his article that Islam does not teach violence or terror, but Islam comprehensively is a religion that upholds nonviolent and built-peace principles [9].

Starting from the principles and beliefs above, Maxima Picture and its friends strive to display more comprehensive Islamic teachings and also as a discourse that needs to be socialized through movie media. From that matter, researchers are interested in researching and studying it much more in-depth. In this study, the focus to be discussed is to find out how the Bulan Terbelah di Langit Amerika represents a message of peace and explains Islam comprehensively and reveals the truth of good Islamic teaching.

\section{Theorical Framework}

\subsection{Movie as Mass Communication Medium}

According to Fiske, movies have the power and ability to reach many social segments because the movie has the potential to affect the external audience [10]. It should be acknowledged that the relationship between movie and community has a long history in the study of communication experts - much research on the impact of movie on society [11]. The relationship between movie and society is always linear and is understood [12], meaning that the movie affects and forms the community based on the message payload behind it without applying otherwise [10].

It was reviewed from a type of movie consisting of a story movie, documentary movie, animated movie, and news movie. The emergence of television spawned movies in other forms such as Serial movies (series movies), continuous movies (Telenovela and soap operas), and so on. The movie is divided into four movies, action movies, drama movies, comedy movies, and Propaganda Movies.

The Movie has several messages contained in several groups [13]:

i. Strengthen attitudes, the content of messages in the Movie can strengthen individual attitudes that exist in the community.

ii. Changing attitudes, the Movie indirectly also resulted in no slight changes, which are sometimes considered trivial.

iii. Moving, meaning after an attitude or a pattern

iv. The behavior is strengthened; the media is functioning channeling, controlling it in a specific direction.

v. Offering an individual ethics or value system, meaning the Movie also publicly discloses specific storage of a community's prevailing norms (for example, the Jim Bakker scandal), can present corporate ethics to audiences [14].

The Movie also has the following functions [15]:

i. Movie as a means of information, the effectiveness of two-way transformation that can be used as an intermediary in conveying messages and give images of events. 
ii. Movie as a means of cultural transformation, meaning culture is the result of human thought. The transformation of culture is the cultural displacement of the next generation.

iii. Movie as a means of entertainment, meaning entertainment is a human need, so the function of this one aims so that anyone watching the Movie can feel entertained and eliminate saturation, so that rediscover the freshness and new spirit After watching a movie.

iv. Movie as a means of da'wah, meaning the Movie is expected to give the message of wisdom and moral message so that the connoisseur of the Movie and able to retrieve the moral message in the Movie because every Movie is not all open in Give his message. Sometimes through satire/contact, which can be interpreted by the movie connoisseur [16].

v. movie as a means of education, meaning Movie can also be used for learning media. Here the Movie is used to streamline communication and interaction between educators and students in the education network process [17].

vi. movie as a means of fulfillment of commercial needs, meaning the function of the Movie here can sell in the market and many people during showtimes, so that the production of Movie is used as a means of fulfilling financial needs both personal and group [18].

\subsection{Meaning of Peace}

In essence, peace is fundamental in human life, because with peace will create a healthy, comfortable, and harmonious life in every interaction between each other. In a safe and peaceful setting, people will live in peace. Therefore, peace is the absolute right of every individual. Even a peaceful presence in the lives of every creature is a claim because behind the peaceful expression, and it saves friendliness, tenderness, brotherhood, and justice [19].

There is no peace in this world as long as there are individuals whose inner does not get favor peace, so that is the view of Islam [20]. Whoever wants to establish world peace on a reliable and good foundation, he must begin to establish it in one's inner life [21]. The peace that is planted by Islam in the inner individual is the peace that radiates from the regularity and harmony, which is composed of freedom and order [22]; The peace that grows from the power and excellent and constructive strength of the turmoil and the well-educated psychiatric stimulation, not from the weak, stunned and weak souls; Peace that makes every individual recognize its existence, realizing its desires and hopes [23]. Moreover, along with it he also knew the benefits of society and its purpose, knowing the needs of man, and hopes; Know the religion, human and the Idealism, all in its harmony and regularity.

Islam, with the teaching of love, unfortunately, goes even further beyond the boundaries of human life and encompasses other living creatures [24]. A gentle and loving conscience radiates love and friendliness towards every living creature. Islam, with the teaching of love, unfortunately, goes even further beyond the boundaries of human life and encompasses other living creatures [25]. A gentle and loving conscience radiates love and friendliness towards every living creature.

Compassion is a concept that implies a deep psychological meaning; compassion will be understood to mean when the concept is manifested in the form of attitudes, behavior, and human deeds to the other human beings [26]. As God's most perfect creation creature, man has a reason, feeling, and will. According to Sayheed Qutub, compassion is not only required by the Muslims, but it is also required of all humanity [27]. Islam, with the teaching of love, unfortunately, goes even further beyond the boundaries of human life and encompasses other living creatures. A gentle and loving conscience radiates love and friendliness towards every living creature.

\section{Method}

This research includes qualitative research types. Qualitative is a study that does not hold calculations, meaning the data collected intangible numbers but rather words. Qualitative Research methods aim to explain the phenomenon by profuse through the collection of profuse data [28]. The 
semiotic analysis of Charles Sander Pierce is used to detail the message of peace in the Bulan Terbelah di Langit Amerika.

The subject of research, is the movie The Bulan Terbelah di Langit Amerika, by Maxima Picture in 2015. The object of this research is the "message of peace" in the Bulan Terbelah di Langit Amerika movie which includes 2 elements, namely: the first love and compassion that includes; (1) Parents ' affection toward children, (2) Men's affection for women, (3) The affection of fellow human beings. Both solidarity or, please help which include; (1) Help others in emergencies, (2) Please help the children who fall victim to war.

According to Bogdan, data analysis is the process of finding and structuring systematically the data obtained from the smallpox of hands and other materials so that it is easily understood by others. The study used a semiotic analysis of model Charles Sanders Pierce. Semiotics has good potential in analyzing and interpreting the data in the form of text, music, photos, videos, and more [29].

The study examines the movie Bulan Terbelah di Langit Amerika using a semiotic analysis of Charles Sanders Pierce with a triangular theory of its developed meanings. Pierce posited a triangle of meanings, consisting of three main elements, the sign, objects, and concepts formed based on an interpretation of the object (interpretant). A sign is a physical form that can be captured by the human senses and is something that refers to (prenup) other things beyond the mark [30].

\section{Results and Discussion}

The love and affection points featured in the Bulan terbelah di Langit Amerika movie are explained by the scenes presented, in which case researchers take a prominent scene played by two Muslim families in the form of social interactions within the family's internal community. Islam establishes social interaction is the relationship between all individuals in the community is a relationship of affection, faithful companions, and mutual assistance, relationship of tranquility and peace.

As for what has been explained before, that the message of peace that will be researched are the elements that are in the concept of peace itself, one element or concept that can be used as a message of peace and that stands out in the movie Bulan Teerbelah di Langit Amerika is an element of love and compassion. According to Sayeed Qutub, one of the essential elements of building peace is through compassion to others covering the human resources that exist in the family and outside the family itself, namely society.

Peace can materialize one of them using the concept of affection relationship that occurs between man and man. That is classified as (1) Parents ' affection to the Child, (2) male affection toward women, (3) The affection of a fellow man. This is because the above three categories are representations of peace messages, as discussed in Chapter 1. A. Parents ' affection for children.

In the category of a message the affection of parents on children in the purpose of achieving the elements of peace message, researchers will focus the analysis on the interaction scenes between parents to his son, especially in the Muslim family of Ibrahim Hussein with Azima. 
Table 1.

Parent Affection in Bulan Terbelah di Langit Amerika

\begin{tabular}{|l|l|l|l|l|}
\hline No & Scene & Frame & Sign & Unit Analys \\
\hline 1. & 1 & Icon & $\begin{array}{c}\text { isualization a moslem father } \\
\text { give a kiss for his child }\end{array}$ \\
\hline 2. & 40 & Icon & Visualization a moslem mother \\
huge her child
\end{tabular}

Identification and classification of the above signs, obtained by researchers as many as 5 (five) scenes, including two icon marks, 1 (one) index mark and 2 (two) symbol marks. Then the next step of the researcher will describe how the formation of meanings in each scene containing the love and the affection of parents to his son.

In Scene 1, there is a father's scene (Husain) kissing his son's forehead. In this scene, the father used the attributes of the long robe/clothes of Koko and wore a peci. These traits imply a Muslim man. It was seen in the scene that the father was farewell to his son while giving a kiss on the child's forehead. The treatment of parents (Husain) to his son signifies that there is a sense of parental affection to his son.

On this type of icon is the visual parent (father) Muslim kissing his son's forehead. Based on the relationship of the mark with the object and the icon type, the relationship of signs and objects in this visual is the same as a Muslim father who kissed his son and his interpretation led to the love and affection of the elderly (father) to his child.

In this scene, there is love and parental affection to his son, in the perspective of Islam a father or parent is obliged to care for his child with various forms of expression or movement, one of them through the form of movement kissing. Prophet Muhammad even gave a concrete example of how to devote compassion to the child. 
In scene 40, it looks Azima (mother) is hugging Sarah, and this scene shows Azima to hug her son intends to say goodbye because he will depart from work. The second icon mark is the visual Azima (Muslim mother) giving a hug to her child. Based on the relationship of signs with the object on the icon type, the relationship of signs and objects in this visual is the same as the Muslim mother who is hugging the child, and the interpretation describes a mother to pour compassion on her child with Give a hug. The shape of the movement embraced it as a sign and showed the segmentation of parental affection for his son.

In scene 1 It looks a touching atmosphere between a Muslim man (father) with a child (his son). The foreboding atmosphere is because the father will go to leave his son to work. In this scene identifies a father who is said to be separated from his son. The first index type mark is a sad expression, and the sad expression is a painful feeling condition. In this context, the painful feeling was caused by a father who had to part with his son. His painful feelings arose from a father's affection for his son. The depiction of the scene in Scene 1 is a birthday celebration of a child (Sarah) being given a gift or gift from her father (Hussein). What is shown in the scene identifies the existence of affection (gift-giving) parents to their children at the time of their birthdays.

The first type of symbol mark is a visual gift/gift, precisely a father (Hussein) gave a gift to his son, who was a birthday. Prizes or gifts are a tradition or social covenant that exists in every celebration of one's birthday, and it has been blocked in society, no exception in Islam. In this scene depicted a father played by Hussein using attributes of Muslim clothing is giving gifts or gift to his son. In the tradition of society, when someone is a birthday, then it is often found that people give gifts/gift to the person who is celebrating his birthday. Because according to the tradition of gift/gift is a symbol of attention, love, and affection of one's to others, including a father to his son.

The scene formed a scheme, and the effect of forming a man (father) was pouring love, unfortunately by giving gifts to his son. The parent's affection to his son is pictured here is a man who wears a Muslim attribute that has the nature of love, affection, and sincerity. The interpretation is showing that with a beard and a Muslim dress in the movie bulan terbelah di langit amerika, the Muslim Boy (father) gives a gift to his child as a love and affection act.

\section{Conclusion}

After conducting analysis and finding the research results on the message of peace on the moon Movie split in the American sky, researchers gave the following advice: To the moviemakers, researchers hope that every production of movies should consider the interests of the wider community, not only about idealism alone should pay attention to the nature of the media itself, namely informative, educative, and also entertaining As modeled after the Bulan terbelah di Langit Amerika. So in the process of making and post-release to the public, no party feels harmed and feels sucked in the reality of Made in a movie. And it should be in every movie making more a positive message for the audience, not until the movie contains elements that tend to be provocative or nuanced. This is so that there is no misunderstanding and triggers debate in the public, given that there are quite a few movies that raise racial-nuanced things, hurt certain groups, and Intolerance.

To the Bulan Terbelah di Langit Amerika, researchers advise to continue working, creating movies that are not only informative, educative, and entertaining but must have a da'wah mass, given the movie lovers in Indonesia Still thirst for movies with religious nuance. For movie connoisseurs, be a critical, analytical and careful audience in watching movies, so that the messages delivered in the movie can be well-known and perfect, do not be the audience who only accept the message delivered In the movie but should be sorting out which messages are proper to digest and which are not digestible. 


\section{References}

[1] D. Narwoko and B. Suyatno, Sosiologi; Teks Pengantar dan Terapan. Jakarta: Kencana Prenamedia Group, 2006.

[2] U. Jandevi, "New media for increasing political participation in Indonesia," Int. J. Commun. Soc., vol. 1, no. 1, pp. 1-8, 2019.

[3] M. Danesi, Pengantar Memahami Semiotika Media. Yogyakarta: Jalasutra, 2010.

[4] M. Ulfah, C. Fajri, and D. Fadillah, "Pemahaman Literasi media Di Lingkungan Pengurus Pimpinan Wilayah Aisyiyah daerah Istimewa Yogyakarta Periode 2015-2020," Informasi, vol. 47, no. 2, 2017.

[5] H. Hens, "6 Movie Hollywood yang Tampilkan Citra Positif Islam," Fimela, 2015. [Online]. Available: https://www.fimela.com/news-entertainment/read/2544805/6-movie-hollywood-yangtampilkan-citra-positif-islam.

[6] Sukawarsini and Djelantik, Terorisme: Tinjauan Psiko-Politis, Peran Media, Kemiskinan, dan Keamanan Nasional. Jakarta: Yayasan Pustaka Obor Indonesia, 2010.

[7] J. Baudrillards, "Analysis Of Consumption Cultural Studies Essay,” UKEssays.com, 2018. .

[8] J. Baudrillards, Selected Writings. Stanford: Stanford University Press, 1988.

[9] Wikipedia, "Bulan Terbelah di Langit Amerika," Wikipedia, 2015. [Online]. Available: http://cncc.bingj.com/cache.aspx?q=bulan+terbelah+di+langit+amerika\&d=4507469435962700\&mkt =zh-CN\&setlang=en-GB\&w=0STj7eqZkkABwoT0yWqeae_OzOm5TYED.

[10] N. Mambrol, “John Fiske and Television Culture," Literariness, 2018. [Online]. Available: https://literariness.org/2018/07/17/john-fiske-and-television-culture/.

[11] D. Fadillah, L. Zhenglin, and D. Hao, "Social Media and General Elections in Malaysia 2018 and Indonesia 2019," J. Komun. ISKI, vol. 4, no. 1, pp. 1-8, 2019.

[12] J. Fiske, Television Culture. London: Routledge, 1987.

[13] P. N. Dilly, Structure and Function of the Tear Movie. Boston: Springer US, 1994.

[14] H. Effendy, Mari Membuat Movie. Jakarta: Pustaka Kofiden, 2002.

[15] G. Burton, Yang Tersembunyi di Balik Media; Pengantar Kepada Kajian Media. Yogyakarta: Jalasutra, 2006.

[16] M. Ulfah and A. Barry, "Indonesia Leader Forum, post-truth and political interests in social media and television," Int. J. Commun. Soc., vol. 1, no. 1, pp. 17-25, 2019.

[17] W. Sintawati, "Computer mediated communication for construction-supported constructivism in communication and cultural learning," Int. J. Commun. Soc., vol. 1, no. 1, pp. 34-42, 2019.

[18] D. Fadillah, "Model Komunikasi 'WOM' Sebagai Strategi Pemasaran Efektif," Humanika, vol. 15, no. $1,2015$.

[19] K. Jaya, "Venezuela's communication dynamics in rejection of humanitarian assistance from United States of America," Int. J. Commun. Soc., vol. 1, no. 1, pp. 26-33, 2019.

[20] Z. M. Sidiq, "Makna Pesan Perdamaian Dalam Movie (Analisis Semiotika Roland Barthes Mengenai Makna Pesan Perdamaian Dalam Movie Di Timur Matahari Karya Ari Sihasale)," Universitas Komputer Indonesia Bandung, 2014.

[21] N. W. Sari, "Analisis Semiotika Pesan Perdamaian pada Video Klip 'Salam Alaikum Harris J'," Universitas Islam Negeri Syarif Hidayatullah Jakarta, 2016.

[22] H. Fadjri, “'Analisis Pesan-pesan Perdamaian Dalam Lagu Bob Marley,” Universitas Andalas Padang, 2014.

[23] F. F. Lotan, "Making a positive internet through Socmed Agawe Guyub," Int. J. Commun. Soc., vol. 1, no. 1, pp. 9-16, 2019. 
[24] M. Abu-Nimer, Nirkekerasan dan Bina-Damai dalam Islam. Jakarta: Yayasan Abad Demokrasi, 2010.

[25] Z. Mizrawi, Al-Qur'an Kitab Toleransi: Tafsir Tematik Islam Rahmatan Lil Alamin. Jakarta: Pustaka Oasis, 2010.

[26] M. N. Al Albani, Ringkasan Shahih Muslim. Jakarta: Pustaka Azzam, 2013.

[27] S. Qutub, Islam dan Perdamaian Dunia. Jakarta: Pustaka Firdaus, 1987.

[28] D. Fadillah, "Pola Komunikasi Internal Brajamusti Menjelang Pilkada Kotamadya Yogyakarta 2017," Informasi, vol. 47, no. 1, 2017.

[29] N. Hadari, Metode Penelitian Bidang Sosial. Yogyakarta: Gajah Mada University Press, 2003.

[30] R. Kudadiri, “Analisis Semiotika Makna Perdamaian Dalam Movie 'Di Timur Matahari," UPN Veteran Yogyakarta, 2016. 